\title{
Co-infections with Borrelia species, Anaplasma phagocytophilum and Babesia spp. in patients with tick-borne encephalitis
}

\author{
A. Moniuszko • J. Dunaj • I. Święcicka • G. Zambrowski • J. Chmielewska-Badora • \\ W. Żukiewicz-Sobczak • J. Zajkowska • P. Czupryna • M. Kondrusik • S. Grygorczuk • \\ R. Swierzbinska $\cdot$ S. Pancewicz
}

Received: 24 February 2014 / Accepted: 21 April 2014 / Published online: 22 May 2014

(C) The Author(s) 2014. This article is published with open access at Springerlink.com

\begin{abstract}
The purpose of this study was evaluation of the prevalence of co-infection with Borrelia species, A. phagocytophilum and Babesia spp. in patients with tickborne encephalitis (TBE). At total of 110 patients with TBE were included in the study. Serological tests for tick-borne encephalitis virus (TBEV), PCR for Borrelia species, Anaplasma phagocytophilum and Babesia spp., blood smears for A. phagocytophilum and Babesia spp. and BLAST analysis for Babesia spp. were performed. Results showed a significant majority of patients co-infected with Borrelia species (30/110; $27 \%$ ), much less with A. phagocytophilum (12/110; $10.9 \%)$ and with Babesia spp. (1/110; $0.9 \%)$. The BLAST analysis of the $18 S$ rDNA sequence obtained with the Babesia spp. specific primers indicated that the patient was infected with Babesia microti. Triple co-infections (TBEV-Borrelia species- A. phagocytophilum) were observed in three (3/110; $2.7 \%$ ) patients. Conclusions were such that differential diagnosis in patients after the tick bite, presenting with acute symptoms, should include not only TBE and Lyme disease, but also other diseases transmitted by ticks. In patients with
\end{abstract}

Justyna Dunaj is a scholar of project: „Study, research, commercialize UMB doctoral candidate support programme" section 8.2.1 of Operational Programme Human Capital, co-financed by the European Union from the European Social Fund.

A. Moniuszko $(\bowtie) \cdot J$. Dunaj $\cdot$ J. Zajkowska $\cdot$ P. Czupryna $\cdot$

M. Kondrusik $\cdot$ S. Grygorczuk $\cdot$ R. Swierzbinska $\cdot$ S. Pancewicz Department of Infectious Diseases and Neuroinfections, Medical University of Białystok, 14 Zurawia, 15-540 Bialystok, Poland e-mail: annamoniuszko@op.pl

I. Święcicka • G. Zambrowski

Department of Microbiology, Faculty of Biology and Chemistry, University of Białystok, 20 B Swierkowa, 15-950 Bialystok, Poland

J. Chmielewska-Badora • W. Żukiewicz-Sobczak

Department of Allergology and Environmental Hazards, Institute of Rural Health, 2 Jaczewskiego, 20-090 Lublin, Poland low parasitemia in suspicion of Babesia spp. infection PCR seems to be a more sensitive method than blood smear. Coinfection with various tick-borne pathogens must be always considered, especially in endemic regions.

\section{Introduction}

It is known that certain tick species are able to transmit more than one pathogen, e.g. tick-borne encephalitis virus (TBEV), Borrelia burgdorferi sensu lato (Borrelia species), Anaplasma phagocytophilum (A. phagocytophilum), and Babesia species (Babesia spp.), which may be a reason for co-infections [1]. Co-infections are becoming a serious epidemiological and clinical problem, especially due to the fact that the methods of treatment of infectious diseases caused by various tickborne pathogens differ from each other. Therefore, this fact is more frequently considered in clinical research, especially in the areas endemic for tick-borne diseases. We suppose that positive results of PCR tests, especially in patients with nonspecific symptoms in an early phase of infection, when antibodies cannot be detected with the help of traditional methods, may be helpful in the diagnosis and introduction of treatment of zoonoses such as Lyme disease (LD), tick-borne encephalitis (TBE), anaplasmosis or babesiosis.

\section{Objective}

The objective of our study was to evaluate the prevalence of infection with Borrelia species, A. phagocytophilum and Babesia spp. in patients with TBE hospitalized between July 2009 and October 2012 in The Department of Infectious Diseases and Neuroinfections of Medical University of Bialystok, Poland. 


\section{Material and methods}

\section{Material}

A group of 110 patients with TBE (47 female and 63 male) was included in the study. None of patients was vaccinated against TBE and all of them had a history of tick bites. Diagnosis was made on the basis of clinical manifestation, cerebrospinal fluid (CSF) examination and the presence of serum and CSF specific antibodies. Anti/TBEV antibodies titer was measured with SERION ELISA classic TBE Virus $\operatorname{Ig} / \operatorname{Ig} M$ (Institut Virion/Serion GmbH, Germany). Patients presented symptoms as shown in Table 1 . None of them was immunocompromised. Laboratory tests and cerebrospinal tests results, as well as levels of TBEV antibodies are also presented in Table 1.

Serum was collected to search for anti/TBEV and anti/Borrelia burgdorferi antibodies. Whole blood in EDTA was used for PCR for Borrelia species, Babesia spp. and A. phagocytophilum. Blood smears were performed to search for Babesia spp. and A. phagocytophilum circulating stages. Cerebrospinal fluid was collected to perform biochemical, immunological and PCR examination.

Table 1 Laboratory and cerebrospinal tests results, levels of tick-borne encephalitis virus (TBEV) antibodies and symptoms in TBE patients

\begin{tabular}{ll}
\hline Symptoms and laboratory tests results & TBE patients, $N=110$ \\
\hline Headache & $103(93 \%)$ \\
Vertigo & $23(21 \%)$ \\
Nausea & $40(36 \%)$ \\
Vomits & $32(30 \%)$ \\
Fever & $96(87 \%)$ \\
Muscle pain & $20(18 \%)$ \\
Joint pain & $20(18 \%)$ \\
Erythema migrans & 0 \\
Meningeal signs presence & $90(81 \%)$ \\
Anti/TBEV IgM serum (mean) IU/ml & 14 (cut off -0.45$) 98 \%$ of \\
Anti/TBEV IgG serum (mean) IU/ml & 30 (cut off -0.27$) 95 \%$ of \\
Anti/TBEV IgM CSF (mean) IU/ml & 4 (cut off -0.45$) 80 \%$ of \\
& patients were positive \\
Anti/TBEV IgG CSF (mean) IU/ml & $8.8($ cut off -0.27$) 82 \%$ of \\
& patients were positive \\
CRP (mean \pm SD) mg/dl & $11.4 \pm 12.5$ \\
SD (mean \pm SD) mm/h & $27.6 \pm 15.7$ \\
WBC (mean \pm SD) (tys) & $9.1 \pm 3.4$ \\
RBC (mean \pm SD) (mln) & $4.4 \pm 0.5$ \\
PLT (mean \pm SD) $(\times 100$ tys) & $203.4 \pm 56.5$ \\
CSF cytosis (mean \pm SD) cells/ $\mu 1$ & $111 \pm 154.6$ \\
CSF protein concentration & $63.9 \pm 20.7$ \\
(mean \pm SD) (mg/dl) & \\
\hline &
\end{tabular}

A control group (CG) consisted of 20 healthy blood donors, in whom PCR for Borrelia species, Babesia spp. and A. phagocytophilum and blood smears were performed.

The study was approved by the Bioethical Commission of the Medical University of Bialystok.

\section{DNA isolation}

DNA isolation was performed with the $200 \mu \mathrm{l}$ of fresh or kept in $+4{ }^{\circ} \mathrm{C}$ whole blood according to QIAamp DNA Mini Kit (Qiagen, Germany). DNA extracts in $100 \mu$ volume were received from doubled elution by the mini spin column.

\section{PCR amplifications}

For detection of particular tick-borne pathogens: Borrelia species, Babesia spp., A phagocytophilum specific conservative genes were used. Sequence for protozoan Babesia: F2 (5' GAC ACA GGG AGG TAG TGA CAA G 3') and R2 (5'biotin CTA AGA ATT TCA CCT CTG ACA GT 3') amplifying a fragment from V4 region of $18 S$ rDNA gene [2] were synthesized by Sigma-Aldrich (Germany) and performed with Taq PCR Core Kit (Qiagen, Germany). In reaction for Babesia spp., $5 \mu$ l of extracted DNA were added to a reaction mixture (total volume of $50 \mu \mathrm{l}$ ) containing $5 \mu \mathrm{l}$ of buffer $\mathrm{x} 10$ with $15 \mathrm{mM} \mathrm{MgCl}_{2}$ (Qiagen, Germany), $2 \mu \mathrm{l}$ of $25 \mathrm{mM} \mathrm{MgCl}_{2}$, $1 \mu \mathrm{l} 10 \mathrm{mM}$ dNTPs, $1 \mu \mathrm{l} 20 \mu \mathrm{M}$ of each primer and $0.25 \mu \mathrm{l}$ $(5 \mathrm{U} / \mu \mathrm{l})$ Taq DNA polymerase (Qiagen, Germany). The experimental constructed amplification programme included initial denaturation at $94{ }^{\circ} \mathrm{C}$ for $3 \mathrm{~min}, 40$ cycles (denaturation at $94{ }^{\circ} \mathrm{C}$ for $40 \mathrm{~s}$, annealing at $58^{\circ} \mathrm{C}$ for $60 \mathrm{~s}$, extension at $72{ }^{\circ} \mathrm{C}$ for $60 \mathrm{~s}$ ) and final extention at $72{ }^{\circ} \mathrm{C}$ for $10 \mathrm{~min}$ [3-5].

Amplification of $A$. phagocytophilum genetic material was performed with the diagnostic kit PCR Anaplasma (BlirtDNA Gdańsk, Poland) coding a fragment of $16 \mathrm{~S}$ rDNA gene encoding small ribosomal 16S RNA subunit. Analyses were conducted in accordance with the manufacturers instruction, in the period from 2009 to 2011 in single PCR and in 2012 in a nested type of PCR. In conventional, single course PCR in 2011, $1 \mu \mathrm{l}$ of the template DNA isolate was added to $43.7 \mu \mathrm{l}$ of the Master Mix with $5 \mu$ l of dNTPs and $0.3 \mu \mathrm{l}$ of Hypernova polymerase for a final reaction mix volume of $50 \mu \mathrm{l}$. Amplification was performed in the following PCR program: initial denaturation at $94{ }^{\circ} \mathrm{C}$ for $5 \mathrm{~min}, 35$ cycles (denaturation at $94{ }^{\circ} \mathrm{C}$ for $30 \mathrm{~s}$, annealing at $56{ }^{\circ} \mathrm{C}$ for $30 \mathrm{~s}$, extension at $72{ }^{\circ} \mathrm{C}$ for $3 \mathrm{~s}$ ) and final extension at $72{ }^{\circ} \mathrm{C}$ for $2 \mathrm{~min}$. Positive results were $227 \mathrm{bp}$ long fragments of the $16 \mathrm{~S}$ rDNA gene. Nested PCR for A. phagocytophilum DNA detection was performed in two amplifications. In the first, PCROUT $2 \mu \mathrm{l}$ of the template DNA isolates was added to $42 \mu \mathrm{l}$ of the Master Mix with $5 \mu$ of dNTPs and $1 \mu$ of Taq nova polymerase for a final reaction mix volume of $50 \mu \mathrm{l}$. First amplification was performed in the following PCR program: 
initial denaturation at $95^{\circ} \mathrm{C}$ for $2 \mathrm{~min}, 40$ cycles (denaturation at $94{ }^{\circ} \mathrm{C}$ for $30 \mathrm{~s}$, annealing at $55{ }^{\circ} \mathrm{C}$ for $30 \mathrm{~s}$, extension at $72{ }^{\circ} \mathrm{C}$ for $60 \mathrm{~s}$ ) and final extension at $72{ }^{\circ} \mathrm{C}$ for $5 \mathrm{~min}$. In a second amplification, PCR-IN, despite DNA isolate to $42 \mu \mathrm{l}$ of the Master Mix with $5 \mu \mathrm{l}$ of dNTPs and $1 \mu \mathrm{l}$ of Taq nova, $2 \mu \mathrm{l}$ of PCR product from first reaction was added. The PCRIN program follows as in PCR-OUT, but in 30 cycles. Presence of the $16 \mathrm{~S} r D N A$ gene fragments: 932 bp long in PCROUT and 546 bp long in PCR-IN attest to A. phagocytophilum infection. Lack of 932 bp long fragments in PCR-OUT does not exclude a positive result of test.

Borrelia species Molecular detection was performed by using the Borrelia burgdorferi PCR kit (GeneProof, Czech Republic) for in vitro diagnostics. The kit is designed for professional use in specialized clinical and research laboratories. The kit is designed for the detection of Borrelia burgdorferi sensu lato sp. group on the principle of amplification of the specific DNA sequence of a $276 \mathrm{bp}$ fragment of flagellin encoding gene by nested one tube PCR. The template DNA extract was added to $36 \mu \mathrm{l}$ of the MasterMix for a final reaction mix volume of $40 \mu$ l. "Hot start" technology was used in the detection kit, minimizing risk of non-specific reactions and maximizing sensitivity of procedure. Eventual PCR inhibition was controlled by internal standard in the reaction mix. Addition of uracil-DNA-glycosylase (UDG) eliminated possible contamination during preparation of the reaction. Nested PCR was performed in compatibility to GeneProof instruction with our own modifications. The course of the amplification was prepared according to the following reaction program: UDG decontamination at $37^{\circ} \mathrm{C}$ for $2 \mathrm{~min}$, initial denaturation at $96{ }^{\circ} \mathrm{C}$ for $10 \mathrm{~min}$, first amplification for 30 cycles (denaturation at $96^{\circ} \mathrm{C}$ for $20 \mathrm{~s}$, annealing at $68^{\circ} \mathrm{C}$ for $20 \mathrm{~s}$, extension at $72{ }^{\circ} \mathrm{C}$ for $40 \mathrm{~s}$ ), second amplification for 45 cycles (denaturation at $96^{\circ} \mathrm{C}$ for $20 \mathrm{~s}$, annealing at at $54^{\circ} \mathrm{C}$ for $20 \mathrm{~s}$, extension at $72{ }^{\circ} \mathrm{C}$ for $30 \mathrm{~s}$ ) and final extension at $72{ }^{\circ} \mathrm{C}$ for $2 \mathrm{~min}$.

All amplifications were conducted on SensoQuest LabCycler (SensoQuest, Germany). Received PCR products were separated by electrophoresis in $2 \%$ agarose gel (Sigma-Aldrich, Germany) stained with ethidium bromide $(5 \mu \mathrm{g} / 1 \mathrm{ml}$; Syngen, USA). Electrophoresis conditions for A. phagocytophilum and Babesia spp. were $80 \mathrm{~V}$ by $60 \mathrm{~min}$ and for Borrelia species $80 \mathrm{~V}$ by $80 \mathrm{~min}$. The results obtained were viewed under UV light and visualized by Gel Logic System 100 camera (Kodak, Imaging System, Inc., USA) (Figs. 1, 2, 3).

The amplification product for Babesia spp. showed $94 \%$ homology to sequences received in Gen Bank NCBI in positions KC 581934.1, KC 470049.1, AY 789075.1 and $\mathrm{AB}$ 071177.1, which indicated Babesia microti presence.

For A. phagocytophilum the specificity and selectivity were determined by bioinformatic method using the NCBI

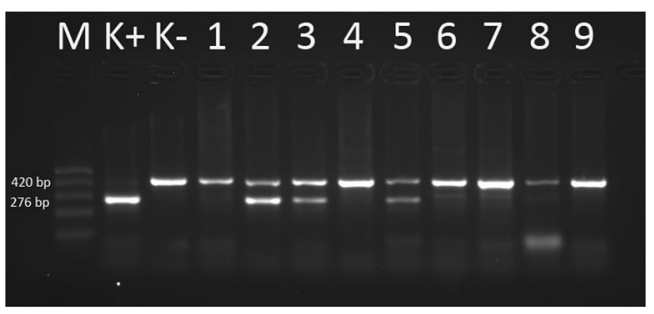

Fig. 1 Electrophoretical detection of amplification of Borrelia burgdorferi sl PCR products on agarose gel. M 100-500 bp molecular weight marker; $\mathrm{K}+$ positive control; $\mathrm{K}$ - negative control; 420 bp-internal standard; 276 bp positive $B$. burgdorferi sl fragments of fla gene; lines: 2,3,5 positive samples; lines: $1,4,6,7,8,9$ negative samples

database. Lack of specificity of tick DNA template kit was confirmed experimentally. Results of analysis showed that the system selectively detects only A. phagocytophilum DNA. In addition, the integrated package does not show homology to DNA templates of other prokaryotes or eukaryotes.

As positive controls we used DNA extracted from a deer spleen infected with Babesia spp.; in Borrelia species and in $A$. phagocytophilum cases a positive control was included in the particular kits. In a negative control redistilled water replaced DNA isolates. The size of amplification products for fla gene of Borrelia species was 276 base pairs (bp), for Babesia spp. $18 S$ rDNA approximately $420 \mathrm{bp}$ and for A. phagocytophilum $16 S$ rDNA $227 \mathrm{bp}$ in the 2009-2011 period and $546 \mathrm{bp}$ in 2012 .

Nucleotide sequencing of the Babesia 18 rDNA amplicon

Amplification products of the Babesia spp. 18S rDNA were purified using the QiaAmp PCR purification kit (Qiagen). Sequencing reactions of both strands were performed using Big Dye Terminator cycle sequencing kit (Applied Biosystems) with the F2 and R2 primers under the same conditions as above. Cycle sequencing reactions were purified using the ExTerminator Kit (A\&A Biotechnology, Gdynia, Poland) and sequenced with the ABI3500 automated

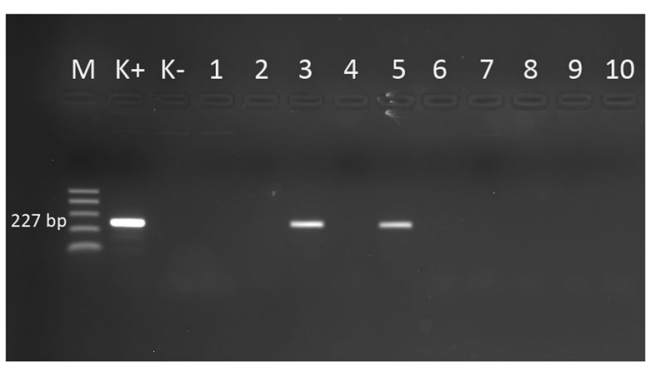

Fig. 2 Electrophoretical detection of amplification of Anaplasma phagocytophilum PCR products on agarose gel. M 100-500 bp molecular weight marker; $\mathrm{K}+$ positive control; K-negative control; 227 bp positive Anaplasma phagocytophilum fragments of $16 \mathrm{~S} r D N A$ gene; lines: 3,5 positive samples, lines: $1,2,4,6,7,8,9,10$ negative samples 


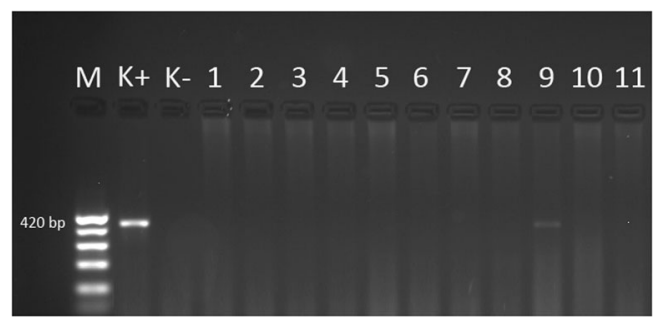

Fig. 3 Electrophoretical detection of amplification of Babesia species PCR products on agarose gel. M 100-500 bp molecular weight marker; $\mathrm{K}+$ positive control; $\mathrm{K}$ - negative control; $420 \mathrm{bp}$ positive Babesia species fragments of $18 \mathrm{~S} r D N A$ gene; line: 9 positive samples; lines: 1, 2, 3, 4, 5, $6,7,8,10,11$ negative samples

sequencer (Applied Biosystems, Foster City, USA). The obtained sequences were compared with sequences collected in the NCBI database (http://www.ncbi.nlm.nih. gov).

Immunoserology diagnostic

The detection of TBE virus infection was performed with SERION ELISA classic TBE Virus IgG/IgM (Institut Virion/ Serion GmbH, Germany) diagnostic kit twice in patients with meningitis or encephalitis, namely, at the time of admission to the hospital and 2 weeks later. Anti/TBEV antibody level dynamics were observed. A level of viral specific IgM and IgG antibodies was marked according to manufacturer's recommendations.

Anti/B. burgdorferi IgM and IgG antibodies in enzymelinked immunosorbent assay (ELISA; Borrelia recombinant IgG and IgM High Sensitivity, Biomedica, Austria) and intrathecal production of anti/B. burgdorferi antibodies (EcoLine test, Virotech Classic Kits, Germany) in cases with suspicion of neuroborreliosis were performed.

\section{Blood smears}

Obligatory, from full blood collected on EDTA, blood smears stained with May-Grunwald and Giemsa (MGG) were performed twice. Piroplasm forms in erythrocytes were searched for Babesia spp. infection and morulae in neutrophiles for A. phagocytophilum infection.

\section{Statistical analysis}

Statistical analysis to compare patients with only TBE infection and co-infections was performed using Statistica 10. Groups were compared by Mann-Whitney and Pearson's chi-squared tests. $P$ value $<0.05$ was considered statistically significant.

\section{Results}

In our study, conducted in the northeastern part of Poland on a group of 110 patients with TBE, a significant majority was coinfected with Borrelia species (30/110; $27 \%$ ), much less with A. phagocytophilum (12/110; $10.9 \%$ ) and with Babesia spp. $(1 / 110 ; 0.9 \%)$. The BLAST analysis of the $18 \mathrm{~S}$ rDNA sequence obtained with the Babesia spp. specific primers indicated that the patient was infected with Babesia microti. One patient was diagnosed as neuroborreliosis, based on anti/B. burgdorferi $\operatorname{IgM}$ and $\operatorname{IgG}$ serum antibodies and intrathecal production of anti/B. burgdorferi antibodies in CSF.

Triple co-infections (TBEV-Borrelia species-A. phagocytophilum) were observed in three $(3 / 110 ; 2.7 \%)$ patients.

In blood smear we observed no piroplasm forms in erythrocytes typical of Babesia spp. infection or morulae in neutrophiles typical of $A$. phagocytophilum infection.

Analysis of patients infected only with TBEV and patients co-infected with other pathogens showed no significant difference in the presented symptoms, which indicates overlapping of symptoms in cases of TBEV infection. However, there were significant differences in the laboratory parameter values such as the erythrocyte sedimentation rate (ESR) $(p=0.028)$ and alanine aminotransferase activity $(p=0.006)$ (Tables 2 and 3 ).

\section{Discussion}

In Poland, similarly to other European countries, tick-borne diseases are an increasing epidemiological and clinical problem. Annual incidence of LD has also been increasing systematically. The number of registered cases in 2005 and 2009 was 4.406 (incidence 11.5/100.000 inhabitants) and 10,333 cases (incidence 27.1/100.000 inhabitants), respectively. During a period of 5 years a 2 -fold increase in LD incidence has been observed. The regions considered to be endemic are the Podlaskie and Warminsko-Mazurskie regions (northeastern Poland) with annual 5-fold higher incidence in comparison to the whole country. In 2012, a total of 9.159 cases were reported (incidence 24/100.000 inhabitants) [6].

TBE incidence has also been increasing for years. The number of registered cases in 2005 and 2009 was 174 (incidence 0.46/100.000 inhabitants) and 344 (incidence 0.9/ 100.000 inhabitants), respectively. In 2012, 188 cases were reported (incidence $0.49 / 100.000$ inhabitants). Similarly to LD most cases have been observed in the Podlaskie and Warminsko-Mazurskie regions [6].

At the moment the exact number of cases suffering from anaplasmosis and babesiosis is unknown. At the same time, it is known that from 1956, only in Europe, more than 50 cases of human babesiosis have been confirmed [7-9]. Human Granulocytic Ehrlichiosis (HGE, anaplasmosis) has been 
Table 2 Comparison of symptoms between patients only with tick-borne encephalitis (TBE) and patients with co-infections

\begin{tabular}{|c|c|c|c|c|c|}
\hline \multirow[t]{2}{*}{ Symptoms } & \multicolumn{2}{|c|}{$\operatorname{TBEV}(N=70)$} & \multicolumn{2}{|c|}{$\begin{array}{l}\text { TBEV }+ \text { B. burgdorferi } \mathrm{s} 1 \mathrm{TBEV}+ \\
\text { A. phagocytophilum } \mathrm{TBEV}+ \\
\text { Babesia } \text { spp. }(N=40)\end{array}$} & \multirow[t]{2}{*}{$p$} \\
\hline & $n$ & $\%$ & $n$ & $\%$ & \\
\hline Headaches & 66 & $94.3 \%$ & 37 & $92.5 \%$ & 0.71 \\
\hline Vertigo & 12 & $17.2 \%$ & 11 & $27.5 \%$ & 0.19 \\
\hline Nausea & 23 & $33 \%$ & 17 & $42.5 \%$ & 0.31 \\
\hline Vomiting & 22 & $31.4 \%$ & 10 & $25 \%$ & 0.47 \\
\hline Muscle pain & 11 & $15.7 \%$ & 11 & $27.5 \%$ & 0.13 \\
\hline Joint pain & 11 & $15.7 \%$ & 9 & $22.5 \%$ & 0.37 \\
\hline Fever & 62 & $88.6 \%$ & 32 & $80 \%$ & 0.21 \\
\hline Meningeal signs presence & 53 & $75.7 \%$ & 24 & $60 \%$ & 0.08 \\
\hline Neck stiffness & 44 & $63 \%$ & 29 & $72.5 \%$ & 0.3 \\
\hline
\end{tabular}

$T B E V$ tick-borne encephalitis virus

diagnosed from 1994 in the United States, from 1996 in Europe and from 2001 in Poland [7]. Despite that, only a few cases have been described. For example, due to the research of Welc-Falecciak et al., in a group of 30 tickexposed people from southeastern Poland only one case of Babesia spp. $(1 / 30 ; 3.3 \%)$ and one of A. phagocytophilum $(1 / 30 ; 3.3 \%)$ infection were confirmed with PCR [8].

It is known that more than one pathogen may co-exist in one vector. According to various European sources, coinfection of $I$. ricinus ticks with different pathogens appears to be quite common [5, 10-13]. In Poland, the prevalence of co-infected $I$. ricinus ticks with at least two pathogens varies from $0.12-8.30 \%$ and depends on the area of tick sampling [1, 14-16].

Human co-infection with various pathogens may be the result of a single tick bite by the tick infected with more than one pathogen or the result of multiple bites by ticks infected with one pathogen. Both situations may result in a coinfection, often difficult to diagnose and differentiate [17]. Meer-Scheerer et al. described a case of B. microti and Borrelia species co-infection [18]. Krause et al. observed that in 1156 serosurvey subjects, $97(8.4 \%)$ were seroreactive

Table 3 Comparison of laboratory test results between patients only with tick-borne encephalitis (TBE) and patients with co-infections

\begin{tabular}{|c|c|c|c|c|c|c|c|}
\hline \multirow[t]{2}{*}{ Laboratory parameters } & \multicolumn{3}{|c|}{$\operatorname{TBEV}(N=70)$} & \multicolumn{3}{|c|}{$\begin{array}{l}\text { TBEV }+ \text { B. burgdorferi } \mathrm{sl} \mathrm{TBEV}+ \\
\text { A. phagocytophilum } \mathrm{TBEV}+ \\
\text { Babesia } \mathrm{spp} .(N=40)\end{array}$} & \multirow[t]{2}{*}{$p$} \\
\hline & Mean & SD & Median & Mean & SD & Median & \\
\hline $\operatorname{ESR}(\mathrm{mm} / \mathrm{h})$ & 34 & 21 & 30 & 45 & 19 & 46 & 0.028 \\
\hline CRP (mg/l) & 9.9 & 10.8 & 7.5 & 14.4 & 15.2 & 8.4 & 0.16 \\
\hline $\mathrm{RBC}(\mathrm{mln} / \mu \mathrm{l})$ & 4.45 & 0.54 & 4.4 & 4.48 & 0.44 & 4.6 & 0.47 \\
\hline Hemoglobin (g/dl) & 13.5 & 1.45 & 13.5 & 13.6 & 1.1 & 13.7 & 0.75 \\
\hline Hematocrit (\%) & 40.1 & 8.3 & 39.9 & 39.4 & 3.4 & 39.5 & 0.9 \\
\hline WBC (tys/ $/ \mu \mathrm{l})$ & 9.03 & 3.2 & 9.02 & 9.13 & 4 & 9.3 & 0.98 \\
\hline PLT (tys/ $\mu 1)$ & 208 & 59 & 208 & 194 & 51 & 194 & 0.3 \\
\hline ALT (U/l) & 34 & 37 & 22 & 21 & 25 & 13 & 0.006 \\
\hline AST (U/1) & 28 & 23 & 21 & 20 & 8 & 17 & 0.14 \\
\hline LDH (U/l) & 315 & 514 & 199 & 236 & 72 & 238 & 0.28 \\
\hline Creatinine (mg/dl) & 0.76 & 0.15 & 0.74 & 0.77 & 0.17 & 0.78 & 0.62 \\
\hline Glucose (mg/dl) & 99 & 16 & 99 & 103 & 31 & 95 & 0.71 \\
\hline Fibrynogen (mg/dl) & 464 & 196 & 415 & 455 & 144 & 474 & 0.88 \\
\hline Bilirubin (mg/dl) & 1.25 & 1.6 & 0.62 & 0.67 & 0.27 & 0.57 & 0.92 \\
\hline
\end{tabular}

$T B E V$ tick-borne encephalitis virus 
against LD spirochete antigen, of whom 14 (14\%) also were seroreactive against babesial antigen [19]. Varis et al. described patients simultaneously infected with TBEV and $B$. burgdorferi spirochete as a result of a single tick bite [20]. Cimperman et al. also identified patients who had ELISA serum IgM and IgG antibodies of TBEV and a positive PCR result for TBEV in cerebrospinal fluid as well as Borrelia species isolated from cerebrospinal fluid [21]. Hermanowska-Szpakowicz et al. observed patients with LD $(8 / 96 ; 8.3 \%)$ and patients with TBEV (4/96; $4.1 \%)$ coinfected only with $A$. phagocytophilum, but not with Babesia microti [7].

In our study conducted in northeastern Poland we observed a rate of co-infections of $2.7 \%$ : B. burgdorferil A. phagocytophilum/TBEV. However, we observed a quite high rate of co-infection with TBEV and Borrelia species (27\% of patients with TBEV were positive for Borrelia species), which was not observed in other studies. It may be explained by pre-selections of patients, who were admitted to hospital due to suspected meningitis. We also noticed a patient with Babesia microti infection, which was asymptomatic or with mild course. This observation may suggest significantly higher importance of Babesia infection than it has been considered previously.

Various methods may be used to diagnose infections caused by tick-borne agents. Among these are serological examinations (TBE, LD, babesiosis, anaplasmosis), PCR (LD, TBE, babesiosis, anaplasmosis) and blood smear (babesiosis, anaplasmosis) [22]. Each of these methods might be used separately and it is not necessary to have positive results of all of them simultaneously. The ideal situation would be to obtain the same results from all available methods; however, none of them has $100 \%$ specificity and sensitivity. Blood smear, which in some cases may be negative, is the best example of problems in the diagnostic process. In general, the analysis of blood smears is a fairly subjective process. The need to discriminate the subtleties of babesial/anaplasmal morphology and possible low parasitemias may result in inaccurate diagnoses, which might require further analysis.

In cases of anaplasmosis suspicion 25-75\% of patients have morulae in peripheral blood smear examinations, with the highest sensitivity during the first week of infection [23]. Only one-third of patients with babesiosis have piroplasm forms in erythrocytes in microscopic study [21]. Additionally, Aktas et al. observed in sheep blood samples that only in four out of 98 piroplasms B. ovis forms were present in thin blood smears, whereas in PCR 21 samples were positive [24]. If there is a strong suspicion of anaplasmosis or babesiosis and parasitemia is low, detection of parasites may by difficult on a thin blood smear, and molecular techniques are recommended [22].

From the clinical point of view the influence of coinfections on the course of disease and treatment administration is the most important issue. Logina et al. analyzed 51 patients with double infection-TBEV and Borrelia species - and concluded that the clinical occurrence of both LD and TBE varies after exposure to tick bite, and the neurological manifestations of each disorder differ significantly, with appreciable overlap [25]. However, their study provided no proof that co-infection manifested with extraordinary symptoms due to unexpected interaction between these two pathogens. Nevertheless, they suggest that all the patients from endemic areas presenting with acute neurological symptoms after the tick bite should be investigated for both LD and TBE and simultaneous treatment of both conditions should be introduced as quickly as possible.

In another study of 687 patients with TBE $2 \%$ were diagnosed with neuroborreliosis. They more frequently had pleocytosis of over 300 cells $/ \mathrm{mm}^{3}$ and statistically higher concentration of protein $(88.2 \mathrm{mg} / \mathrm{dl}$ vs $67.4 \mathrm{mg} / \mathrm{dl})$. In the group without neuroborreliosis, symptoms like headaches, vertigo, nausea and vomiting were more frequent than neurological symptoms in comparison to the group with neuroborreliosis [26].

On the other hand, Alekseev et al. suggested that Borrelia species might suppress viral replication in ticks and in TBEsusceptible individuals, hence it is still a matter of controversy [27]. In our study no differences in clinical picture between patients with only TBE infection and co-infection with other tick-borne pathogens were stated.

Grab et al. suggested that $A$. phagocytophilum co-infection contributes to the severity, dissemination and possible sequelae of LD. They showed that co-infection enhanced reductions in transendothelial electrical resistance and enhanced or synergistically increased production of metalloproteinases, cytokines and chemokines, which are known to affect vascular permeability and inflammatory responses [28].

Co-infection with Babesia and Borrelia species may influence the clinical course, especially in non-immunocompetent patients, and might be difficult to diagnose due to the fact that both diseases cause nonspecific symptoms, such as fever, fatigue, and flu-like illness. Patients with an inadequate response to appropriate therapy for proven or suspected LD following a tick bite should be examined for infections with other tick-borne agents, including Babesia species [28]. It is also worth remembering during travel to endemic areas for tick borne diseases, as babesiosis is starting to appear as a travel-related disease [29].

We assume that administration of antibiotic therapy in cases suspected of co-infection should be introduced as soon as possible and should be verified after the advanced laboratory test results, such as molecular biology methods (e.g. PCR). We also should be aware that number of pathogens transmitted on humans by ticks is constantly increasing (e.g. Fransicella tularensis, Bartonella spp., spotted fever rickettsiae group and many others) and further studies are necessary [30]. 


\section{Conclusions}

1. Nonspecific symptoms after tick bite may results from presence of other than TBEV pathogens, not diagnosed routinely.

2. In patients with low parasitemia in suspicion of Babesia spp. PCR seems to be a more sensitive method than blood smear.

3. Co-infection with various tick-borne pathogens must always be considered, especially in regions endemic for these diseases.

Conflict of interest The authors declare that they have no conflict of interest.

Open Access This article is distributed under the terms of the Creative Commons Attribution License which permits any use, distribution, and reproduction in any medium, provided the original author(s) and the source are credited.

\section{References}

1. Skotarczak B, Rymaszewska A, Wodecka B, Sawczuk M (2003) Molecular evidence of co-infection of Borrelia burgdorferi sensu lato, human granulocytic ehrlichiosis agent, and Babesia microti in ticks from northwestern Poland. J Parasitol 89:194-196

2. Pichon B, Egan D, Rogers M, Gray J (2003) Detection and identification of pathogens and host DNA in unfed host-seeking Ixodes ricinus L. (Acari: Ixodidae). J Med Ent 40:723-731

3. Gubbels MJ, de Vos AP, van der Weide M, Viseras J, Schouls LM, de Vries E, Jongejan F (1999) Simultaneous detection of bovine Theileria and Babesia species using reverse line blot hybridization. J Clin Microbiol 37:1782-1789

4. Oura CAL, Bishop RP, Wampande EM, Lubega GW, Tait A (2004) Application of reverse line blot assay to the study of haemoparasites in Uganda. Int J Parasitol 34:603-613

5. Piccolin G, Benedetti G, Doglioni C, Lorenzato C, Mancuso S, Papa N, Pitton L, Ramon MC, Zasio C, Bertiato G (2006) A study of the presence of B. burgdorferi, anaplasma (previously Ehrlichia) phagocytophilum, Rickettsia, and Babesia in Ixodes ricinus collected within the territory of Belluno, Italy. VBZD 6:24-31

6. National Health Institute (2013) Infectious diseases and poisonings in Poland (annual report). http://www.pzh.gov.pl/. Accessed 1 Nov 2013

7. Hermanowska-Szpakowicz T, Skotarczak B, Kondrusik M, Rymaszewska A, Sawczuk M, Maciejewska A, Adamska M, Pancewicz S, Zajkowska J (2004) Detecting DNA of Anaplasma phagocytophilum and Babesia in the blood of patients suspected of Lyme Disease. Ann Agric Environ Med 11:351-354

8. Welc-Falęciak R, Hildebrandt A, Siński E (2010) Co-infection with Borrelia species and other tick-borne pathogens in humans: two cases from Poland. Ann Agric Environ Med 17:309-313

9. Gray J, Zintl A, Hildebrandt A, Hunfeld KP, Weiss L (2010) Zoonotic babesiosis: overview of the disease and novel aspects of pathogen identity. Ticks Tick Borne Dis 1:3-10

10. Hildebrandt A, Fritzsch J, Franke J, Sachse S, Dorn W, Straube E (2011) Co-circulation of emerging tick-borne pathogens in middle Germany. Vector Borne Zoonotic Dis 11:533-537

11. Lommano E, Bertaiola L, Dupasquier C, Gern L (2012) Infections and coinfections of questing ixodes ricinus ticks by emerging zoonotic pathogens in Western Switzerland. Appl Environ Microbiol 78:4606-4612
12. Schorn S, Pfister K, Reulen H, Mahling M, Silaghi C (2011) Occurrence of Babesia spp., Rickettsia spp. and Bartonella spp. in Ixodes ricinus in Bavarian public parks, Germany. Parasit Vectors 4:135

13. Reis C, Cote M, Paul RE, Bonnet S (2011) Questing ticks in suburban forest are infected by at least six tick-borne pathogens. Vector Borne Zoonotic Dis 11(7):907-916

14. Skotarczak B, Wodecka B, Cichocka A (2002) Coexistance DNA of Borrelia burgdorferi sensu lato and Babesia microti in Ixodes ricinus ticks from north-western Poland. Ann Agric Environ Med 9:25-28

15. Stańczak J, Gabre RM, Kruminis-Łozowska W, Racewicz M, KubicaBiernat B (2004) Ixodes ricinus as a vector of Borrelia burgdorferi sensu lato, Anaplasma phagocytophilum and Babesia microti in urban and suburban forests. Ann Agric Environ Med 11:109-114

16. Wójcik-Fatla A, Szymańska J, Wdowiak L, Buczek A, Dutkiewicz J (2009) Coincidence of three pathogens (Borrelia burgdorferi sensu lato, Anaplasma phagocytophilum and Babesia microti) in Ixodes ricinus ticks in the Lublin makroregion. Ann Agric Environ Med 16: $151-158$

17. Swanson SJ, Neitzel D, Reed KD, Belongia EA (2006) Co-infections acquired from ixodes ticks. Clin Microbiol Rev 19:708-727

18. Meer-Scherrer L, Adelson M, Mordechai E, Lottaz B, Tilton R (2004) Babesia microti infection in Europe. Curr Microbiol 48:435-437

19. Krause PJ, Telford SR 3rd, Spielman A, Sikand V, Ryan R, Christianson D, Burke G, Brassard P, Pollack R, Peck J, Persing DH (1996) Concurrent lyme disease and babesiosis evidence for increased severity and duration of illness. J Am Med Ass 275:1657-1660

20. Varis A, Oksi J, Järveläinen H (2011) Central nervous system infection tick-borne encephalitis, neuroborreliosis or both? Duodecim 127:75-79

21. Cimperman J, Maraspin V, Lotric-Furlan S, Ruzić-Sabljić E, AvsicZupanc T, Strle F (2002) Double infection with tick borne encephalitis virus and Borrelia burgdorferi sensu lato. Wien Klin Wochenschr 114:620-622

22. Krause PJ, McKay K, Thompson CA, Sikand VK, Lentz R, Lepore T, Telford SR, Persing D, Radolf JD, Spielman A (2002) Deerassociated infection study group. disease-specific diagnosis of coinfecting tickborne zoonoses: Babesiosis, human granulocytic ehrlichiosis, and lyme disease. Clin Inf Dis 34:1184-1191

23. Ismail N, Bloch KC, McBride JW (2010) Human ehrlichiosis and anaplasmosis. Clin Lab Med 30:261-292

24. Aktaş M, Altay K, Dumanli N (2005) Development of a polymerase chain reaction method for diagnosis of Babesia ovis infection in sheep and goats. Vet Parasit 133:277-281

25. Logina I, Krumina A, Karelis G, Elsone L, Viksna L, Rozentale B, Donaghy M (2006) Clinical features of double infection with tickborne encephalitis and lyme borreliosis transmitted by tick bite. $\mathrm{J}$ Neurol Neurosurg 77:1350-1353

26. Czupryna P, Moniuszko A, Pancewicz SA, Grygorczuk S, Kondrusik M, Zajkowska J (2011) Tick-borne encephalitis in Poland in years 1993-2008-epidemiology and clinical presentation. A retrospective study of 687 patients. E J Neurol 18:673-679

27. Alekseev AN, Dubinina EV, Vashukova MA, Volkova LI (2001) Borreliae as possible antagonists of tick-borne encephalitis virus: parasitologic and clinical aspects. Med Parazitol 3:3-11

28. Grab DJ, Nyarko E, Barat NC, Nikolskaia OV, Dumler JS (2007) Anaplasma phagocytophilum-Borrelia burgdorferi co-infection enhances chemokine, cytokine, and matrix metalloprotease expression by human brain microvascular endothelial cells. Clin Vacc Immunol 14:1420-1424

29. Hunfeld KP, Lambert A, Kampen H, Albert S, Epe C, Brade V, Tenter AM (2002) Seroprevalence of Babesia infections in humans exposed to ticks in midwestern Germany. J Clin Microbiol 40:2431-2436

30. Poisnel E, Ebbo M, Berda-Haddad Y, Faucher B, Bernit E, Carcy B, Piarroux R, Harlé JR, Schleinitz N (2013) Babesia microti: an unusual travel-related disease. BMC Infect Dis 22:13-99 